\title{
The Super-Legality of the Constitution, or, a Federalist Critique of Bruce Ackerman's Neo-
}

\section{Federalism}

\author{
Jack N. Rakove ${ }^{\dagger}$
}

From the time when I first read Bruce Ackerman's Storrs Lectures, Discovering the Constitution, ${ }^{1}$ I have found the project we now know as We the People an exciting enterprise. In part, this was because Ackerman's concept of a "dualist Constitution" 2 capable of engaging in two distinct modes of lawmaking seemed to parallel a question that had already begun to interest me. Where Ackerman's notion distinguishes routine forms of ordinary lawmaking from occasions when the voice of the people speaks in a deeply sovereign pitch, my own concern involved wondering how one could distinguish occasions when constitutional argumentation is merely instrumental from those when it requires more sincere and authentic efforts to grapple with the meaning of the constitutional text. During the course of ordinary politics, I assume, most constitutional argumentation naturally favors those interpretations of relevant constitutional provisions that support the political outcomes we prefer. Constitutional positions are rarely adopted for disinterested or abstract reasons; they are the dependent variables of political argumentation. But there must be other occasions when the Constitution itself moves to the forefront of debate and where political actors and engaged citizens have to make a good faith effort to ask, What does the Constitution mean or require? One thinks: for example, of the events of the early 1970 s, when the controversies over the extent of

† Coe Professor of History and American Studies, Stanford University; Visiting Professor, New York University School of Law. This essay was written and first presented during a stay as a visiting professor at the New York University School of Law, and it is a pleasure to acknowledge how much intellectual support and good cheer I derived from my colleagues there, including Larry Kramer, Larry Sager, Chris Eisgruber, Amy Adler, David Richards, Pasquale Pasquino, and especially my fellow Stanford visitor, John Ferejohn. I owe special thanks to Mary Kimble for many kind acts, and to Dean John Sexton for making my visit possible.

1. Bruce A. Ackerman, The Storrs Lectures: Discovering the Constitution, 93 YALE L.J. 1013 (1984).

2. For an introductory exposition, see 1 BRUCE ACKERMAN, WE THE PEOPLE: FoUNDATIONS 3-33 (1991). 
presidential warmaking powers and Watergate led to serious engagement with fundamental questions of constitutional design. ${ }^{3}$ While political concerns were never absent from these debates, constitutional inquiry took on a more serious - one might say principled — cast. The Constitution itself became an independent variable in our politics. While my concern with distinguishing instrumental modes of constitutional argumentation from occasions when constitutional controversy requires an authentic inquiry is not, of course, identical to Ackerman's distinction between ordinary and higher modes of lawmaking, it resembles it well enough to explain why I found his work so interesting.

As a historian of the Founding era, I also found Ackerman's work engaging for other reasons. For one, it represents an intriguing and influential example of the "turn toward history" that is so striking a feature of contemporary legal scholarship. For another, Ackerman's desire to lay a normative foundation for future constitutional transformations also illustrates one of the great ironies of our constitutional history since 1789. No one can spend any significant measure of time studying the Founding era without realizing that the constitution writers of the 1770s and 1780 s genuinely understood the world-historical quality of the opportunity that the Revolution had thrust upon them. John Adams sounded this note quite clearly in concluding his seminal pamphlet of 1776, Thoughts on Government, by exulting at "hav[ing] been sent into life, at a time when the greatest law-givers of antiquity would have wished to have lived." 4 Alexander Hamilton struck the same note just as confidently in the opening paragraph of The Federalist, when he observed:

It has been frequently remarked that it seems to have been reserved to the people of this country, by their conduct and example, to decide the important question, whether societies of men are really capable or not of establishing good government from reflection and choice, or whether they are forever destined to depend for their political constitutions on accident and force. ${ }^{5}$

Yet from the vantage point of our contemporary political and constitutional culture, what could seem less plausible than the possibility that Americans could ever undertake the project of sustained constitutional deliberation with anything like the confidence or enthusiasm of our political forebears? The mere thought of another constitutional convention sends

3. Or, for that matter, one thinks of the recent impeachment controversy, though here the argument for the instrumental nature of constitutional argumentation seems more pertinent.

4. JOHN ADAMS, THOUGHTS ON GOVERNMENT, reprinted in 1 THE FOUNDERS' CONSTITUTION 107-10 (P. Kurland \& R. Lerner eds., 1987). 1961).

5. THE FEDERALIST No. 1, at 89 (Alexander Hamilton) (Benjamin Fletcher Wright ed., 
tremors down our collective spine: Who knows what mischief would ensue? Yet does it not betray the very premise of the Revolution and the Constitution that we should forever depend on the form of constitutional government laid down two hundreds years ago? Hence the irony: A regime founded on confidence in reason, reflection, choice, and deliberation has become one in which future exercises of those attributes seem difficult to imagine.

Bruce Ackerman senses this irony, but because irony is the more natural trope of the detached historian than the earnestly engaged legal advocate, his own normative commitment to the possibility of constitutional transformation leads him to adopt a more optimistic, indeed, preachy tone. Ackerman warmly welcomes the prospect of future constitutional transformation; much of the historical argumentation of We the People can be read as an effort to legitimate the possibility of further transformations of a similarly sweeping if unspecified kind. A working historian has no basis for assessing this commitment; it is not something he can evaluate within the parameters of his own craft, except, perhaps, by posing as a Mandevillean skeptical of all naive projects of reform. Yet, as an ironist, the historian can reflect on the uses that Ackerman makes of the three historical episodes that beguile him: Founding, Reconstruction, and the New Deal. The irony that I find most intriguing is the one to which this essay will be devoted. Ackerman's account of the Founding events of the 1780 s goes to great lengths to stress the underlying illegality of the whole originating constitutional enterprise; yet in so doing it risks ignoring the substantial progress in constitutional and legal theory that the Framers of the Constitution achieved. The adoption of the Constitution, I will suggest, cannot be explained simply as a problematic exercise in higher lawmaking that gained authority only through a process of political legitimation; it also rested on the capacity of the Framers and their Federalist supporters to exploit new norms of constitutionalism that had only become available since 1776.

Four distinct claims link Ackerman's treatment of the Founding moment of the late $1780 \mathrm{~s}^{6}$ to the larger exposition of higher lawmaking, popular sovereignty, and engaged citizenship that provides the controlling themes of the two volumes (thus far) and supplementary articles that

6. It is important to note that Ackerman's "moments" are indeed momentary-that is, highly episodic and compressed. His treatment of Revolutionary constitutionalism is essentially about the period 1786-1789, not the larger process that began with the drafting of the state constitutions in the mid-1770s. Ackerman's Reconstruction similarly covers only the period 1865-1868, and his analysis of the New Deal crisis focuses almost exclusively on the period 1935-1938. This narrowness of focus leaves important questions about the aftermaths and denouements of these dramatic moments unanswered. 
constitute his intriguing synthesis of how "We the People" have made our constitutional history.

First, the Federalist project to replace the Articles of Confederation with the Constitution framed by the Philadelphia Convention and ratified by the state conventions was an "illegal"-indeed, "flagrantly illegal"enterprise, and its illegality in turn anticipates and resembles the similar problematics that mark the two other transformative moments of Reconstruction and the New Deal.

Second, the five-stage process-signaling, proposing, triggering, ratifying, and consolidating-whereby the Federalists co-opted existing institutions and popular constituencies into acceding to their illegal enterprise also describes the later episodes of the 1860s and 1930s. Not only have there been three distinct moments of higher lawmaking requiring a radical exercise of popular sovereignty, but these episodes all conform to a common pattern of mobilization first pioneered by the revolutionary reformers of the $1780 \mathrm{~s}$. In this process, initial doubts about the illegality of the proposed constitutional alterations are overcome as the political triumphs of the reformist movements bestow legitimacy on their programs. ${ }^{7}$

Third, the Federalists' initial success in this respect in turn provides an additional measure of legitimacy for their Republican and New Deal successors. Those who came later should, in effect, be accorded the same respect Americans customarily reserve for the Founders, for all were engaged in equivalent exercises. And indeed, because our norms of sovereignty have become more democratic over time, the more recent expressions of the will of the American people should trump earlier ones. ${ }^{8}$

Fourth, there is another sense in which the later transformations are to be judged superior to the Founding labors of Madison and his peers. Because a central purpose of We the People is to demonstrate how transformative changes occur beyond the rules of Article V, Ackerman rejects the formalist (or hypertextualist) assumption that only those changes that fully comply with its procedures can be accepted as truly constitutional. In pursuing this point, he challenges the precedential authority of the Founding in two ways. He argues that the very consideration of Article $\mathrm{V}$ was too casual to require its interpretation to be bound by the principle of expressio unius est exclusio alterius. ${ }^{9}$ Inadvertently or otherwise, the Framers left other avenues of constitutional change (tantamount to amendment) available. ${ }^{10}$ In addition, the failure or inability of the Founders

7. See 2 BRUCE ACKERMAN, We THE PEOPLE: TRANSFORMATIONS 66-68, 85-88 (1998).

8. See 2 id. at 88-91, 383-89.

9. "A maxim of statutory interpretation meaning that the expression of one thing is the exclusion of another." BLACK's LAW DICTIONARY 581 (6th ed. 1990); see 2 ACKERMAN, supra note 7 , at 75-77.

10. See 2 ACKERMAN, supra note 7, at 75-77. 
to match later generations' notions of political inclusiveness frees us from being too constrained by the formal amendment mechanisms they imposed. ${ }^{11}$ Our understanding of popular sovereignty is superior to theirs.

A good claim can be made that Ackerman's theory of constitutional transformation does not depend on establishing deep connections between the Founding and later events. Notwithstanding the passion with which he urges readers to take The Federalist to heart, Ackerman has much more invested in his accounts of Reconstruction and the New Deal than in his story about the $1780 \mathrm{~s}^{12}$ It is not exactly news, after all, that the Framers and their Federalist supporters played fast and loose with the requirements of the Articles of Confederation-yea, even to the point of "illegality"-to get the Constitution adopted. Progressive historians, and even more the neoProgressives who studied at the feet of Merrill Jensen, ${ }^{13}$ have always been willing to remind us that the constitutional politics of the 1780 s wasn't bean-bag. But to question the juridical underpinnings of the Reconstruction amendments and the New Deal switch, the foundation stones of nearly all that matters in twentieth-century constitutional jurisprudence-well, Bruce (as our self-addressing author might say), that's serious stuff. ${ }^{14}$ The account of the Founding may still be useful, in part because it purports to establish the model of the five-stage transformative process, but in the larger scheme of the project it is more important (one suspects) for the work it performs in legitimating the later applications of the theory.

Nevertheless, the obvious purpose of this Symposium is to evaluate the historical foundations of Ackerman's constitutional theory, and to do so by asking those of us who contrive to spend our waking hours in the past to reflect on the merits and defects of his appropriation of the scholarship of

11. See 2 id. at $88-91$.

12. This may explain why his treatment of the Founding in Foundations seems rather skimpy. In response to the criticisms of his colleague, Akhil Amar, in The Consent of the Governed: Constitutional Amendment Outside Article V, 94 COLUM. L. REV. 457 (1994), Ackerman and his student, Neal Katyal, published Our Unconventional Founding, 62 U. CHI. L. REV. 475 (1995). This article provided the substantial narrative of the events of 1787-1788 that was missing from Foundations and that is now incorporated as the third chapter of Transformations. As a historian, I confess to having misgivings about the composition of this work. I elaborate on these misgivings in a concurrent review of TRANSFORMATIONS and AKHIL REED AMAR, THE BILL OF RIGHTS: CREATION AND RECONSTRUCTION (1998). See Jack N. Rakove, Two Foxes in the Forest of History, 11 YALE J.L. \& HUMAN. 191 (1999).

13. Merrill Jensen (1905-1980) taught early American history at the University of Wisconsin for nearly half a century. With his numerous students, he is widely credited with preserving the Progressive interpretation of the Revolutionary era at a time when many of its premises and findings were coming under significant scholarly assault. His book, THE NEW NATION: A HISTORY OF THE UNITED STATES DURING THE CONFEDERATION, 1781-1789 (1950), remains an outstanding narrative of the events surrounding the adoption of the Constitution. It was Jensen, too, who first conceived the project of compiling THE DOCUMENTARY HISTORY OF THE RATIFICATION OF THE CONSTITUTION (1976-) that his students, John Kaminski and Gaspare Saladino, have carried on since his death.

14. See 2 ACKERMAN, supra note 7, at 116. 
particular fields. In making these assessments, each of us must stipulate the standards by which he thinks a sympathetic scholar working in a cognate field - but with an avowedly distinct agenda of his own-should be judged. Here are mine:

(1) There is no point in berating legal scholars for not writing history as we would do it, and especially for not providing textured accounts that incorporate the ambiguities, ironies, and indeterminacies in which historians can freely revel. The rhetorical conventions of legal writing are shaped by advocatorial and even adversarial norms that historians may well deem alien, and even off-putting, but that are clearly appropriate to their native discipline. ${ }^{15}$

(2) For Ackerman, as for other scholars (in disciplines other than law) who have followed the recent "turn toward history," the evidence of the past remains something to be used and applied, and not merely rendered for its own sake. In this case, Ackerman applies this history to support a theory of constitutionalism that, while resting on historical foundations, is still driven by primarily normative concerns.

(3) Insofar as We the People also presents a theory of recurring historical change, as expounded in the five-stage model of transformation, it is not the kind of interpretation in which historians engage. This is precisely because we rarely venture beyond the chronologically bounded areas of research to which the costs of professional training and our investment in sources consign us. In this sense, Ackerman's use of history arguably owes more to his alter ego as a political scientist than any yearning desire to pose as historian manqué.

(4) Having offered all these concessions to suggest that historians should suspend their normal disbelief about judging the work of interlopers, the fact remains that strong claims about history are fundamental to the argument of We the People. If the history is deeply flawed, as some of Ackerman's legal critics have already concluded, the theory must be judged defective as well. ${ }^{16}$ While lack of texture may be expected in a work of this nature, acts of omission that slight important developments, or efforts to collapse key distinctions between the event-episodes, offer legitimate grounds to criticize both the history and the theory it supports.

The substantive sections of this essay offer three sets of reservations about the merits of Ackerman's treatment of the Founding. The first

15. I must confess that the rhetorical form of We the People is a bit cloying for my eighteenth-century tastes. I would venture the further opinion that with a modicum of serious editing these first two volumes (totaling nearly nine hundred pages) could have been published as one at half the total length.

16. See David R. Dow, The Plain Meaning of Article V, in RESPONDING TO IMPERFECTION: THE THEORY AND PRACTICE OF CONSTITUTIONAL AMENDMENT 117, 131-44 (Sanford Levinson ed., 1995); Michael J. Klarman, Constitutional Fact/Constitutional Fiction: A Critique of Bruce Ackerman's Theory of Constitutional Moments, 44 STAN. L. REV. 759 (1992). 
examines the arresting claim about the illegality of the Federalist campaign to propose and adopt the Constitution by mechanisms unknown to the Articles of Confederation. The second develops this point by contrasting the innovations of the American revolutionary era with the antecedents of seventeenth-century English constitutionalism-and in doing so it expresses the historian's natural tendency to distinguish rather than elide events. The third asks whether the deep reservations about non-Article $\mathrm{V}$ modes of revising the Constitution voiced by James Madison, most notably in The Federalist Nos. 49 and 50, undermine Ackerman's use of the Founding to legitimate the transformations of Reconstruction and the New Deal.

\section{THE ILLEGALITY QUESTION}

While the ordinary citizens with whom Ackerman at his most optimistic wants to engage might be troubled to learn that the Constitution was the fragrant fruit of "flagrant illegality," jaded scholars are likely to go them one better by admitting (with apologies to Captain Reynaud) that "[w]e are shocked, shocked! to discover that the Federalists played fast and loose with the rules of their constitutional game." We are not really shocked, of course, because the basic charge is well known and easily proven, if certain assumptions about how one defines legality and illegality are not carefully examined. In a true assertion of expressio unius, Article XIII of the Confederation required that all amendments to the charter of federal union be proposed by the Continental Congress and then ratified by each of the thirteen state legislatures, just as the Confederation had been tortuously framed and ratified between 1776 and $1781 .{ }^{17}$ That requirement had erected two significant barriers to the ongoing efforts to amend the Articles (efforts that antedated, by a few weeks, the actual inauguration of the Confederation on March 1, 1781). First, the unanimity requirement proved impossible to meet. Second, insofar as any effort to enhance the authority of Congress would occur at the expense of the state legislaturesassuming one adopts a zero-sum model of the distribution of sovereign powers between two levels of government ${ }^{18}$ - the legislatures were unlikely

17. The standard account (I hope) should be JACK N. RAKOVE, THE BEGINNINGS OF NATIONAL POLITICS: AN INTERPRETIVE HISTORY OF THE CONTINENTAL CONGRESS (1979). It might be noted that Article XWI did not in fact provide the sole practical mechanism for amending the Articles. Individual state cession of western land claims had the effect, by 1784, of giving Congress effective jurisdiction over the Northwest Territory. To be sure, such a result had been anticipated in 1776-1777, but efforts of the so-called landless states to vest territorial powers in Congress had been successfully resisted by those states holding significant claims to the interior. See id. at 155-56, 159-60, 179, 352-54.

18. Whether a zero-sum model is appropriate is indeed a good question. As Peter Onuf has persuasively argued, in many ways adoption of the Constitution actually strengthened the states' 
to acquiesce in any significant reduction in their own authority. To these structural barriers the lone star-crossed state of Rhode Island added a compelling political problem. Widely perceived as an "anti-federal" state through the $1780 \mathrm{~s}$, its government in the grips of a populist paper-money party, Rhode Island balked at even sending a delegation to Philadelphia, making the idea that its legislature might approve anything done there all the less likely. If the Framers could plausibly infer that Article XIII had to be violated in one respect (to circumvent the unanimity rule), why should they feel obliged to honor it in another (to circumvent the presumed reluctance of state legislatures to surrender power)?

To these well-known concerns, however, Ackerman adds a striking emphasis on just how radical a move the decision to abandon Article XIII nonetheless was. It was not only illegal but "revolutionary" - albeit not in the mode of Leninist desperados ready to smash the system, but of "revolutionary reformers" engaged in "institutional jujitsu," seeking legitimacy for their actions by gaining the necessary political support (from both institutions and voters) at each crucial stage. ${ }^{19}$ Ackerman is absolutely correct, I believe, in calling attention to the candor and fervor with which, at key moments, leading Federalists and their acolytes justified the necessity of abandoning Article XIII. The texts providing proof include key statements from James Wilson at the Convention and Madison's Federalist No. 40. But Ackerman provides other sources as well, and still others could have been cited. When, for example, the Pennsylvania assembly was impatiently awaiting word that the Continental Congress had given the Constitution its imprimatur so that it could proceed to call a state convention, leading Federalists (including two Framers) argued that the Confederation and its rules for amendment could be ignored because they were already under "sentence of death," as Hugh Henry Brackenridge so artlessly exclaimed. ${ }^{20}$

So Ackerman is right to emphasize just how willing the Framers and their supporters were to act on "revolution principles" rather than allow deference to the existing rules to prevent the pursuit of the greater good. But to equate their political entrepreneurship with "illegality" seems problematic on a variety of grounds.

Start with the implications of the word "illegal" itself. One suspects the word is deployed more for shock value than anything else. For Ackerman,

authority, principally by guaranteeing that each would survive as a unit of equal quasi-sovereign jurisdiction with both mutual recognition and greater protection of boundaries that were vulnerable to threats to their territorial autonomy. See PETER S. ONUF, THE ORIGINS OF THE FEDERAL REPUBLIC: JURISDICTIONAL CONTROVERSIES IN THE UNTTED STATE, 1775-1787, at 186-209 (1983).

19. ACKERMAN, supra note 7 , at $10-15$.

20. JACK N. RAKOVE, ORIGINAL MEANINGS: POLITICS AND IDEAS IN THE MAKING OF THE CONSTITUTION 110-11 (1996). 
illegality inheres in the "end run" that the Federalists conducted around the requirements of Article Xm. But he is even more anxious to demonstrate that at every step in this process the Framers secured the consent of those who were in the most authoritative position to ascertain what was legal and what was not. No delegate appeared at the Constitutional Convention who had not been elected by the legislature of his state. Congress approved the calling of the Federal Convention and subsequently endorsed its decision to transmit the Constitution to the state legislatures. With the exception of Rhode Island, the legislatures in turn agreed to hold elections for the ratification conventions whose approval the Framers sought, not only to minimize the risk that the legislatures might balk at diminishing their own power, but also to establish a legal basis for the supremacy of the Constitution over the long run.

As a citizen, I have always assumed that when one does something illegal, one can be held legally accountable for one's actions. But on what basis would any delegate to Philadelphia, any member of Congress, any state legislator, or any state convention delegate have been charged for participating in this process? Who would have brought the charges? In what court would they have been tried? And if convicted, or found legally responsible in some other way, what punishment would have been imposed? Even the true revolutionary instigators, the Framers themselves, could have pled that they had done nothing more than ignore the instructions and expectations under which they were to act. But since they could do nothing conclusive in their own right-since they were merely proposing, not disposing - the worst crime of which they could have been accused, had the proposed Constitution come to naught, was of committing a profound error in political judgment and wasting the opportunity they had worked so hard to create. It is true that a Federalist crowd in Philadelphia dragooned two opposition legislators who had absented themselves from their legislative duties in an effort to break up the assembly quorumthereby thwarting action on the calling of a state convention-but what sort of majoritarian would worry about a little duck-soupy violence of this kind?

Of course, there are forms of "illegality" that might fall short of criminality. The fact that the Framers escaped legal prosecution-or even impeachment-for the political high crime and misdemeanor of evading Article XIII or defying their formal instructions does not mean that they had abided by the prevailing legal standards of the day. Ackerman's indictment in fact rests upon a different conception of legality, one that presupposes that the existing framework of public law constituted a sufficiently authoritative and conclusively established set of norms that the Framers willfully transgressed. The critical components of that framework were the initial state constitutions and the Articles of Confederation, documents that (with the exceptions of the Massachusetts and New Hampshire 
constitutions) had been drafted by the fall of $1777 .{ }^{21}$ Though Ackerman has almost nothing to say about this true founding "moment" of American constitutional innovation, ${ }^{22}$ his account assumes that it effectively established a mature regime whose authority and boundaries were well known and consensually accepted. But suppose one thinks of that first phase of American written constitutionalism in somewhat differentarguably more historicized - terms: as a hasty experiment undertaken in the midst of a revolution, by reformers who did not have complete leisure to think through the implications of their actions and who had not yet fully learned to regard a written constitution as supreme fundamental law. Might the positions taken by the Framers and Federalists a decade later seem a measure or two less seditious (or "illegal"), if we could argue that neither the early state constitutions nor the first federal constitution (the Articles of Confederation) were adopted under conditions that enabled them to attain the full legal authority that American doctrine after 1787 would ascribe to written constitutions? Or, to pose the problem another way, does Ackerman's account of the Founding events of 1787-1788 ironically treat as legally authoritative the one prior "moment" in our constitutional history that was arguably the most unconventional of all: the revolutionary transfer of authority from empire to republic that occurred during the months surrounding the decision for independence $?^{23}$

21. In the corporate colonies of Rhode Island and Connecticut, government continued under the authority of their colonial charters. See Willi PAUL ADAMS, THE FIRST AMERICAN CONSTTTUTIONS: REPUBLICAN IDEOLOGY AND THE MAKING OF THE STATE CONSTTTUTIONS IN THE REVOLUTIONARY ERA 66-67 (Rita \& Robert Kimber trans., 1980).

22. And the omission seems the more surprising because in his first volume, Ackerman devotes several appreciative pages to the one scholar who has analyzed the drafting of the first state constitutions most powerfully. But in his comments on GORDON S. WOOD, THE CREATION OF THE AMERICAN REPUBLIC, 1776-1787 (1969), Ackerman seems more intent on those of Wood's points that accord most closely with his own concerns, rather than with assessing the thrust of that book on its own terms. See 2 ACKERMAN, supra note 7, at 212-21.

23. In a very general way, my thinking on this subject has been stimulated by Ruti Teitel, Transitional Jurisprudence: The Role of Law in Political Transformation, 106 YALE L.J. 2009 (1997), which suggests the need to describe periods of transition between an ancien regime whose authority has been rejected and the new constitutional order to be established as distinct in themselves. It follows from such an account that a steady-state description of existing legal structures, of the kind that Ackerman postulates for 1787, cannot capture the inherently uncertain nature of the forms of authority being established and exercised in the midst of a revolutionary transition. If we treat the period 1776-1789 as a sustained transition of that kind-an entirely plausible way to think of it-then the idea that well entrenched and consensually accepted norms of constitutional (higher-law) governance were already in place (awaiting Federalist transgression) becomes more problematic. Though Teitel is more concerned with the vexatious question of the legal basis on which the new constitutional order may prosecute and punish agents of the vanquished illiberal order for their repressive acts, her argument for establishing a distinct theory of what she calls (with some reference to Ackerman) "Transitional Constitutionalism," see $i d$. at 2057-77, has, I believe, wider implications. 
Rather than quibble about the accuracy of the term "illegality," ${ }^{24}$ then, we might better ask whether Ackerman's account adequately describes the deeper constitutional theory on which the Federalist "end run" around Article XIII was based. For Ackerman, the eventual legal supremacy of the Constitution was ultimately the product of the political legitimacy it gained through his five-stage process. By contrast, and not without irony, political historians have been more inclined to emphasize the distinctly legalist way in which Madison and his peers thought about what was necessary to make a constitution fully constitutional (in the sense in which Americans were now coming to think of such documents as written expressions of supreme law). For in the decade since Americans had first begun writing constitutions during the higher lawmaking moment of the mid-1770s, some of them had come to think that both the original state constitutions, and by extension the Articles of Confederation, were legally defective because they had been adopted (or one might say, promulgated) only through the acts of state legislatures and not submitted to the people for ratification. Ackerman briefly acknowledges this point, but he does not expound its significance. ${ }^{25}$ This omission in turn leaves his account stunted in crucial respects.

The first revolutionary constitutions were written by the provincial conventions that exercised effective power in nearly all the American colonies during the interregnum preceding independence. These bodies were conventions in the same (historical) sense that Ackerman uses the term: defective legislatures that, like the English Convention Parliament of $1688,{ }^{26}$ could not act lawfully because one essential branch (the executive) was no longer present. ${ }^{27}$ As independence neared, provincial authorities became increasingly anxious to restore lawful government, and in early 1776 Congress began authorizing the colonies, first individually and then collectively, to undertake the necessary measures. Except in the corporate colonies of Connecticut and Rhode Island, this required innovation, in part

24. While we are quibbling, though, I might add that the choice of "secessionist," 2 ACKERMAN, supra note 7, at 64, to describe the eleven states that formed the reconstituted Union after Rhode Island and North Carolina rejected the Constitution seems a little curious, even if technically accurate. Also disingenuous is the notation that "of fifty-five delegates, only thirtyeight [sic] signed the final proposal." 2 id. at 53 . In fact, of the 42 delegates still present when the Convention adjourned, only three (George Mason, Edmund Randolph, and Elbridge Gerry) refused to sign. Of the other 13 delegates who had previously attended the Convention, only four (John Lansing and Robert Yates of New York, Luther Martin and John F. Mercer of Maryland) became Anti-Federalists. Mercer attended the Convention for only a fortnight in August, with little constructive effect.

25. See 2 ACKERMAN, supra note 7, at 82 .

26. Since the English had not yet adopted the Julian calendar, which made January 1 the new year, the Convention that assembled in January thought it was still 1688. Ackerman omits the usual designation of o.s. that indicates this usage. I will follow modern usage.

27. Govemors in the royal and proprietary colonies could hardly be expected to collude with the colonial legislatures in mobilizing resistance to Britain; governors would naturally use their prerogative to prevent the legislatures from meeting. 
because something had to be done to reconstitute the missing executive branch of government, but more importantly, because reformist impulses were already at work. ${ }^{28}$ In several states, circumstances permitted voters to make a fresh election of delegates before the provincial conventions took up the task of constitution-drafting, so that it might be argued that the revolutionary electorate had authorized a new contract of government ex ante. But there was a war on, ${ }^{29}$ and these conventions did not have the luxury of confining their deliberations to higher lawmaking alone. Pennsylvania was the one state in which the public enjoyed some opportunity to comment on the work in progress, and some revisions were apparently made as a result. But in none of the states drafting constitutions concurrently with independence was the new charter of government submitted for ratification. ${ }^{30}$ The early constitutions were promulgated, not ratified.

In the years to come, these circumstances-so natural a reflection of the revolutionary turmoil-made it possible for critics to allege that the state constitutions were in some sense juridically defective. Because the provincial conventions had also been acting in a merely legislative capacity, doing all that was necessary to carry on the war, the constitutions they had drafted were not expressions of higher lawmaking; they were essentially statutory. If so, then the constitutions were vulnerable to violation under the interpretative maxim of quod leges posteriores priores contrarias abrogant - that is, if two statutes of different dates appear to conflict, the more recent enactment should take precedence over the earlier one. Jefferson made this procedural (but one could also say substantive) defect in the adoption of the Virginia constitution the subject of an important passage in his Notes on the State of Virginia ${ }^{31}$ and James Madison, though often reluctant (as we shall see) to follow Jefferson's constitutional thinking in other respects, converted these criticisms into an essential element of his strategy of constitutional reform. Because the Articles of Confederation had received only legislative ratification, state legislatures that subsequently acted to violate some provision of the Confederation would arguably be within their rights to do so. Rather more tenuously, Madison suggested that this merely statutory form of ratification turned the Confederation into a mere "league of sovereign powers" whose mutual obligations ceased to

28. This, of course, is the point of departure for WooD, supra note 22 .

29. A non-trivial fact that readers of Wood's monumental work might otherwise forget.

30. In Pennsylvania, the failure to submit the constitution to popular ratification contributed to the intensely partisan divisions that remained unresolved in 1787. See WoOD, supra note 22, at 226-37.

31. ThOMAS JefFerson, NOTES ON THE STATE OF VIRGINIA, reprinted in THOMAS JEFFERSON: WRITINGS 123, 246-51 (Merrill D. Peterson ed., 1984). 
bind whenever any of the contracting parties chose to violate one of its provisions. ${ }^{32}$

The one state that had pioneered an alternative method of constitutional adoption was Massachusetts. There the efforts of the General Court to assert an authority to frame a new constitution provoked a populist response, initiated by the town of Concord, which insisted on a new twofold procedure in which the constitution was to be framed by a convention elected for that purpose alone, and then ratified only after its submission to the towns for their approval. It took the good people of Massachusetts nearly four years to reach agreement on these principles, and even then the failure of the convention to specify precisely how the towns should express their approval left the form of ratification several degrees short of unambiguity. ${ }^{33}$ Even so, the Massachusetts precedent provided an innovative demonstration of how procedures might be devised to distinguish a written constitution, conceived as an expression of fundamental law and adopted at a particular moment of historical time, from all other forms of law. Once the special attributes of such a procedure were recognized, it would become possible not only to remove ambiguities surrounding the initial adoption of a constitution, but also (and more important) to lay a powerful foundation for its ultimate legal supremacy. For when a sovereign people directly assented not only to the convention called to propose a constitution, but also to the constitution itself, the doctrine of popular sovereignty acquired a new and more potent meaning. The ex post ratification of a constitution was a more authoritative expression of popular sovereignty than the ex ante authorization of a convention to propose a constitution.

32. For Madison's allusion to the Confederation as a "league of sovereign powers," see Memorandum of James Madison on The Vices of the Political System of the United States (Apr. 1787), in 9 THE PAPERS OF JAMES MADISON 345, 352-53 (Robert A. Rutland et al. eds., 1975); see also Letter from James Madison to George Washington (Apr. 16, 1787), in id. at 382, 385 (emphasizing that to have legitimacy, ratification must be obtained from the people); Letter from James Madison to Edmund Pendleton, (Apr. 22, 1787), in id. at 394, 395 (same). For further discussion, see RAKOVE, supra note 17, at 96-102; and Gerald Stourzh, Constitution: Changing Meanings of the Term from the Early Seventeenth to the Late Eighteenth Century, in CONCEPTUAL ChANGE AND THE CONSTITUTION 35, 35-54 (Terence Ball \& J.G.A. Pocock eds., 1988).

Amar relies on Madison's equation of the Confederation with a league to suggest that the process of constitutional adoption in 1787-88 was indeed legal because existing violations of the Articles had in effect annulled their binding authority, leaving Americans free to exercise a natural right to alter governments whenever they saw fit. See Amar, supra note 12, at 465-69. Ackerman and Katyal refute this claim by noting, I believe correctly, that Madison failed to persuade other Framers to accept his analysis. See Ackerman and Katyal, supra note 12, at 539-59. In my view, Amar misunderstands the nature of the division of sovereignty that was a prominent feature of American federalism from its inception. See RAKOVE, supra note 17, at 135-91.

33. The entire documentary record of this key innovation in American constitutionalism can be found in THE POPULAR SOURCES OF POLITICAL AUTHORITY: DOCUMENTS ON THE MASSACHUSETTS CONSTITUTION OF 1780 (Oscar Handlin \& Mary Handlin eds., 1966). 
The precedent set in Massachusetts was the one that Madison and his allies invoked at Philadelphia and that their Federalist supporters sustained in the states during the course of the ratification struggle. That they had expedient reasons to violate the Articles of Confederation cannot be denied. Rhode Island's refusal even to send a delegation to the Federal Convention indicated that compliance with the rule of unanimous state ratification would doom any serious reform to the same fate as earlier proposed amendments to the Confederation. Once it was clear that the Confederation had to be violated in that respect, it became easier to imagine how its other formal requirement-ratification by the state legislatures-could also be abandoned. Yet expediency alone does not explain why the Framers insisted that the Constitution would have to be approved by popularly elected conventions rather than the state legislatures. A submission to the latter would not only make approval of the Constitution less likely; it would also derogate from its authority over the long (interpretative) run. For a Constitution ratified legislatively would always be vulnerable to the principle of quod leges posteriores priores contrarias abrogant; any subsequent legislature choosing to violate a national constitutional norm would be lawfully entitled to do so, because its lawmaking authority could not be deemed inferior to that of prior meetings of the same body.

Moreover, insofar as the Constitution would immediately circumscribe the legislative authority of the states, securing the unambiguous assent of the people through the calling of popular conventions would have the effect of validating this reduction in the autonomy of the states. After all, in most states the people had never been given the opportunity of consenting directly to the actual constitutional texts under which they were governed; but now, in consenting to the new Federal Constitution, they would ratify not only its new authority but its circumscription of the governing charters of their individual states. Properly considered, in light of the evolution of American doctrine since 1776, the original unratified state constitutions were not truly constitutional at all. But no such insult could be leveled against the proposed Federal Constitution. It would be adopted in the manner most consistent with the leading edge of American constitutional theory: framed by a lawfully authorized body appointed to deliberate on the sole question of constitutional reform itself; undistracted by the press of other business and with four months of leisure to devote to its charge; having no ulterior motives to pursue, because its members could not know whether they would exercise power under the framework they were establishing; and willing to entrust their work to the enlightened judgment of the people at large, gathered in extraordinary meetings that were the closest approximation imaginable, short of a plebiscite for which there were 
no precedents, to a direct expression of popular sovereignty. This policy was definitely expedient, but it was no less deeply principled for that fact. ${ }^{34}$

Madison and other Framers understood, then, that the mode of constitutional adoption that they proposed to pursue involved more than a set of strategic maneuvers designed to outflank the requirements of Article XIII and the imputation of "illegality" and to secure constitutional legality through political legitimacy. Their concept of ratification rested on a superior grasp of the nature of constitutionalism itself. It was a new understanding that drew upon elements of thought that had been available in $1776^{35}$ but that had not been adequately synthesized or appreciated until the precedent of Massachusetts and the admitted hurdles the Federalists had to surmount provided an occasion to do so. Ackerman is certainly correct to stress how much the latter concern (the "illegality" problem) was a factor in Federalist political calculations. But that was only half-and, it might be suggested, the less interesting half-of the story. The rapid, if often turbulent, progress of thought in the decade after independence had produced a more mature and sophisticated understanding of constitutionalism that enabled the Founders to ground their Constitution on foundations that were better designed and sturdier than those available in 1776. In stressing the revolutionary nature of the transformation of 17871788 , Ackerman ignores the even more explicitly revolutionary dimension of the initial acts of constitutional formation a decade earlier. In the midst of a revolution and at the outset of an ongoing experiment in constitutionalism, could it be expected that the "compilers" (as Madison once described them) of the early charters would sort through all problems at once? The same urgent distractions that required the provincial conventions and the Continental Congress to fight a war and draft constitutions simultaneously also constrained their ability to canvass every issue. It was to be expected that failures of imagination, a natural incapacity to anticipate, and the propensity of politicians as well as generals to refight old battles would leave significant problems unforeseen or unresolved. ${ }^{36}$

The moral of this story, then, is that the adoption of the Constitution was an exercise far more in super-legality than illegality or even extralegality. Only if one assumes that a mature, fully articulated concept of

34. I rely here on the much more extensive discussion in RAKOVE, supra note 20, at 102-08.

35. This theme is stressed in the recent book by MARC W. KRUMAN, BETWEEN AUTHORITY AND LIBERTY: STATE CONSTITUTION MAKING IN REVOLUTIONARY AMERICA (1997), which argues, contrary to Gordon Wood, that in 1776 Americans already possessed a firm understanding of the nature of a constitution as a limitation upon all institutions of government.

36. Thus in his letter to Caleb Wallace, assessing the merits of the existing state constitutions, Madison correctly notes that a natural desire to correct the excesses of royal governors led the authors of the first constitutions to exaggerate the danger of executive misconduct while ignoring the prospect of legislative misrule. See Letter from James Madison to Caleb Wallace (Aug. 23, 1785), in 8 THE PAPERS OF JAMES MADISON 350, 350-52 (William M.E. Rachel et al. eds., 1973). For a historical development of the same point, see WOOD, supra note 22, at 132-50. 
constitutionalism had emerged, Pallas Athena-like, at the moment of independence, does it make sense to claim that violation of entrenched, legalistic norms was the signal feature of the Federalists' ratification strategy.

\section{THE ENGLISH PRECEDENT}

The significance of the development of a distinctive American doctrine of constitutional ratification becomes more apparent when set in the context of the important English antecedents of the seventeenth century. The concept of ratification of a fundamental compact of government was not something that the American revolutionaries had to fabricate from whole cloth; it was one of the many ideas that the colonists inherited from the revolutionary and constitutional turmoil of Stuart England. But in the antecedent English case, what is most striking is how underdeveloped and undeployed this concept remained-even though such noteworthy political thinkers as Hobbes, Harrington, and Locke all engaged the question. The difference between the tentative and academic nature of English expressions of this idea, on the one hand, and the robust development of a true constitutional doctrine in America, on the other, reinforces the previous section's emphasis on the deeper legality of the American achievement. What had appeared in seventeenth-century England as a rather problematic idea too abstract in theory and radical in its politics to be acted upon became, in America, the very basis for the establishment of both a new constitutional regime and the legal supremacy of the document that defined its essential features.

For Ackerman, the principal connection between English antecedents and American practice lies in the precedents that the Convention Parliament of 1689 set for both the Federal Convention of 1787 and the celebrated 39th Congress that framed the Fourteenth Amendment (and that Ackerman repeatedly describes as the Convention/Congress). The Parliament that gathered to ascertain whether James II had forfeited the kingship and to determine who would next occupy the throne was legally defective. Not only had James cancelled the writs of election and added insult to injury by throwing the Great Seal in the Thames in his first (unsuccessful) bid to leave England, but his very absence (after he was allowed to escape to France) meant that Parliament was not legally assembled. The Convention nevertheless proceeded to convey the throne to William of Orange and his wife Mary (James's Protestant daughter), and in doing so, to make William's acceptance of the Declaration of Rights a condition of his accession. While that Declaration took the form primarily of an assertion of ancient rights that James had violated, its repudiation of crucial prerogative powers claimed by the Stuart kings did mark a resolution of recurring 
constitutional questions, and its acceptance by William thus made it into a constitutional document of major significance. As Lois Schwoerer has persuasively argued, the Declaration changed the kingship as well as the king. ${ }^{37}$ Leading articles of the Declaration "dealt with royal prerogatives that lie at the very heart of sovereignty: royal power respecting law, military authority, and taxation" ${ }^{38}$ others conclusively vindicated claims of parliamentary privilege that the Stuarts often had honored more in the breach than in the observance..$^{39}$

These events, Ackerman suggests, provided later generations of Americans with a crucial precedent. For the Founders, it offered "a language that permitted them to present their rule-breaking initiative in a way that fell short of total revolution. As in 1688, the Federalist conventions of 1787-1788 had broken some basic rules but had created credible institutional linkages to the preexisting constitution." 40 So, too, the Reconstruction Congress can be compared, in one key respect, with the Convention Parliament. "Just as the seat occupied by the King was painfully empty in Westminster Hall in 1688, so too the seats occupied by the Southern states remained empty in the Senate and House chambers." ${ }^{41}$ But the mandate that Congress sought for its great constitutional proposal, the Fourteenth Amendment, "would be subjected to a far more democratic series of tests than anything imagined in 1688 or $1787, " 42$ presumably because the enlarged democratic electorate of the mid-nineteenth century could speak far more authoritatively than the narrower "political nations" of late Stuart England or Revolutionary America.

Ackerman never suggests, of course, that the members of the Convention/Congress of 1866 consciously looked back to 1689; that juxtaposition appears only for rhetorical effect. The connection between the Convention Parliament and the Federal Convention carries more weight, for 1689 was a precedent of which the Framers were certainly aware (though their failure to attach a declaration of rights to their own Constitution adds an ironic twist to the connection). More important, Ackerman rightly notes

37. LOIS G. SCHWOERER, THE DECLARATION OF RIGHTS, 1689, at 281-91 (1981) (summarizing the conclusions of a very closely argued work that examines both the drafting and the contents of the document). It cannot be said that William's statement accepting the Declaration amounted to a crystal-clear endorsement of its provisions. See The Declaration of Rights (1688-1689), reprinted in SCHWOERER, supra, at 295, 298. Nor would one want to claim that the promulgation of the Declaration of Rights constituted a true Ackermoment of chronologically compressed dimensions, for it took nearly a quarter century of ongoing controversy to work out the implications of 1689. See generally J.H. PLUMB, THE GROWTH OF POLITICAL STABILITY IN ENGLAND 1675-1725 (1967).

38. SCHWOERER, supra note 37, at 283.

39. See id.

40. 2 ACKERMAN, supra note 7 , at 81 .

41. 2 id. at 81 .

42. 2 id. at 163 . 
the crucial contrast between the more robust conception of a convention that the Federalists (for all their illegalities) deployed and the implication of deficiency on which the English conception of a Convention Parliament rested. "The Convention of 1688 was profoundly embarrassed by its defective legality," Ackerman observes. ${ }^{43}$ "In contrast, the Federalist conventions claimed to speak for the People better than the established Congress and state legislatures. In a remarkable inversion, the legally problematic character of the conventions was taken as a sign of their superior capacity to speak for the People." ${ }^{44}$

The distinction between seventeenth-century English conceptions of a convention and other mechanisms of constitutional change and the American practice and doctrine of the next century could benefit, however, from greater attention than Ackerman's passing references provide. Beyond their precedential value, the English antecedents of the Stuart era are instructive for more profound reasons. As often as the English started down the road of radical constitutional reform in this era-executing one king, deposing another, even living, briefly and at best nominally, under the authority of a written constitution ${ }^{45}$ - the differences between their tentative efforts at establishing a new form of constitutionalism (as opposed to new constitutional arrangements) and the American breakthroughs of the next century seem more striking than the similarities.

This observation is meant not as a chauvinistic assertion of the superiority of American constitutionalism over its British antecedents, but rather as a reminder of the divergence between them. In this comparison, several points deserve mention. ${ }^{46}$

Perhaps the most useful starting point involves the Convention Parliament's understanding of the limits of its own authority. While the idea that the Convention Parliament might indeed act as a constitutional convention was broached during the period immediately preceding its

43. 2 id. at 82.

44. Ackerman's use of the plural, "Federalist conventions," appears to muddy a crucial distinction between the Federal Convention and the state ratification conventions. The justification for the former would not rest, I think, on its superior representative character, but rather on the idea that members of a body appointed for the sole purpose of constitution-drafting could not calculate on actually exercising the governing powers they were fashioning. That consideration would also apply to a ratification convention, enhancing its deliberative capacity as well, but here the crucial consideration would indeed be a representative one.

45. The Instrument of Government of 1653, excerpted in THE STUART CONSTITUTION 16031688: DOCUMENTS AND COMMENTARY 342-48 (J.P. Kenyon ed., 1966).

46. In the paragraphs that follow, I draw synthetically on several works on the constitutional history of the seventeenth century: RICHARD ASHCRAFT, REVOLUTIONARY POLITICS \& LOCKE'S TWO TREATISES OF GOVERNMENT 521-89 (1986); JULLAN H. FRANKLIN, JOHN LOCKE AND THE THEORY OF SOVEREIGNTY (1978); HOWARD NENNER, THE RIGHT TO BE KING: THE SUCCESSION TO THE CROWN OF ENGLAND 1603-1714 (1995); SCHWOERER, supra note 37; Mark Goldie, The Roots of True Whiggism 1688-94, 1 HIST. OF POL. THOUGHT 195 (1980); and Mark Goldie, The Revolution of 1689 and the Structure of Political Argument, 83 BULL. OF RES. IN THE HUMAN. 473 (1980). 
meeting, that notion was no more than a glimmer of a possibility that operated only at the margins of radical politics. If one accepted the line of argument that equated the flight of James II with a dissolution of government-rather than a mere abdication or abandonment or forfeiture of the throne by a discredited monarch - then it presumably followed that the Convention Parliament was not merely an emergency body to fix the succession, but a plenary assembly empowered to devise fundamental constitutional changes. This possibility was scouted in a handful of radical pamphlets; equally intriguingly, it was endorsed by John Locke, still in exile in Holland and furiously revising earlier drafts of the Second Treatise of Government.

In this view, the Convention was neither an inferior nor a defective version of Parliament, but potentially a more authoritative representation of the people of England-and the people not as embodied already in a "commonwealth," one author declared, but as the "community" that preceded it. "A Parliament makes Laws for the Administration; but the People, as in a Community, makes Laws for the Constitution." ${ }^{47}$ Whatever legal defects the Convention faced in acting constitutionally might be overcome if it were extraordinarily representative of the community. What was needed was

A National Convention made up of the Representatives of the Community: That the Convention may be truly National, and represent the Community, it must be larger than a House of Commons ordinarily is. It's this Convention that sets up what kind of Government they please. If they'd have a Parliament made up of King, Lords and Commons, it's sufficient that this Convention is so pleased. The Power of this Convention must be absolute and uncontroulable, accountable to none but God. It gives Laws to kings, yea to the whole Parliament, and sets bounds unto it; it shall go so far, and no farther. No Act of Parliament can be strong enough to move the foundation laid by this Convention. The Convention therefore as it has more Power than a Parliament, as [it] is it's Creator, it must have a larger Body. ${ }^{48}$

Forms of government were not immutable, observed another writerpossibly the aging radical, John Wildman. "But if the Departure of the King amounts to such a Desertion as dissolves the Government, then the

47. ADVICE BEFORE IT BE TOO LATE: OR A BREVIATE FOR THE CONVENTION 3 ([1688 o.s.]). I was fortunate enough to read this pamphlet and others cited below in the Bodleian Library of Oxford University, which may help explain why I treasure these sources.

48. A LETTER TO A FRIEND, ADVISING IN THIS EXTRAORDINARY JUNCTURE, HOW TO FREE THE NATION FROM SLAVERY FOREVER (1689; a tract of two pages). Interestingly, this tract cites the common law maxim of quod leges posteriores to explain why a solution depending on Parliamentary action alone will be inadequate. 
Power must necessarily revert and vest in the People, who may erect a new one, either according to the old Model, if they like it so well, or any other that they like and approve of better." ${ }^{49}$ Locke, too, thought that the Convention should regard itself as having greater authority than a parliament, the better "to find remedies, and set up a constitution that may be lasting, for the security of the civil rights, and the liberty and property of all the subjects of the nation." 50 If the Convention instead "think of themselves as a Parliament," and proceeded accordingly, "mending great faults piecemeal, or anything less than the great frame of government, they will let slip an opportunity." 51

Some Englishmen-including the one destined to exert the greatest influence over American thinking-thus did not think that the Convention was legally defective, and they were prepared to hold out hopes for farreaching constitutional change, of a kind not unlike that which the Levellers had advocated forty years earlier. But of course the Convention Parliament took a more moderate and prudent path, not least because it was not a solidly Whig revolutionary assembly but a bicameral assembly in which the Lords still sat, while Tories were well represented in the lower chamber. The Convention delegates had no interest in accepting the claim that the government was dissolved merely because it was momentarily kingless; instead, they strenuously debated the exact basis on which the throne had been rendered vacant, and the various steps, both political and constitutional, that had to be taken for it again to be occupied. To any rightminded, red-blooded republican American, the contortions needed to settle the exact status of the monarchy seem like so many latter-day political variations of medieval scholasticism; but in fact settling the monarchy was the central, overriding constitutional problem of the era.

In the early days of the Convention (which got under way on January 22 ), it was by no means evident that resolution of the monarchical question required the promulgation or acceptance of a document like the eventual Declaration of Rights. There were many ways to robe a king, and there were good reasons not to force William to endorse a document he seemed less than eager to accept. But his own publicly avowed reasons for descending on England, coupled with the Whigs' desire to seize the occasion to resolve many of the disputed issues of the century, produced a different result. By linking William's accession directly to his acceptance of

49. JOHN WLLDMAN, SOME REMARKS UPON GOVERNMENT, AND PARTICULARLY UPON THE EstablishmeNT OF THE ENGLISH MONARCHY, RELATING TO THIS PRESENT JUNCTURE, 1 SOMER'S TRACTS 162 (1705).

50. Letter from John Locke to Edward Clarke (Feb. 7, 1689), quoted in FRANKIIN, supra note 46, at 121. That Locke understood his Second Treatise as an endorsement of the radical position is the clear conclusion supported by both Franklin and Ashcraft. See id.; ASHCRAFT, supra note 46.

51. Letter from John Locke to Edward Clarke, quoted in FRANKLIN, supra note 46. 
the Declaration, by contriving a ceremony to make that connection explicit, and by subsequently reenacting the Declaration as a statute, the Convention Parliament (and the lawful Parliament that it now became) indicated its intention of altering the constitution in essential respects. The Declaration, its leading student insists, changed the kingship as well as the king, even if its authors felt compelled to present their work in the language of restoring ancient rights rather than forging new rights and understandings. ${ }^{52}$

These are arresting claims, but they merit qualification. The fiction that the deposition of James II and the accession of William III were justified in terms of the restoration of ancient rights provides a useful reminder of the conservative limitations inherent in English thinking by the end of the century. For all the philosophical radicalism that we can ascribe to Hobbes and Locke (in very different respects), the whole point of presenting the Declaration as a work of restoration was to delimit-if not indeed to deny-the very possibility that Americans would grasp a century later: of being able to treat the act of constituting government as a matter of reflection and choice (of precisely the kind that Ackerman celebrates). The glacial progress of the reform of political representation over the next two centuries illustrates just how conservative a legacy the Glorious Revolution left-for what made it glorious was that it could be portrayed in such restorationist, rather than revolutionary, terms. ${ }^{53}$

The Convention Parliament's necessary preoccupation with the monarchy exposes another basic point of divergence between the English precedent of 1688-1689 and the experimental American innovations that took place exactly a century later. Constraining monarchy and determining questions of deposition and succession were admittedly issues of the utmost gravity and consequence, and Englishmen had a perfect right to obsess about them. But a theory of constitutionalism that emphasizes the priority of erecting and maintaining legal checks on hereditary rulers differs in fundamental respects from the problems of constitutional design that engaged Americans a century later. True, as the avowed heirs of seventeenth-century English political discourse, the American revolutionaries retained much of that age's belief in the checking functions of constitutionalism. But it is possible to see in the American experiments-and particularly in James Madison's fascination with ideas of representation and legislation - a more advanced definition that views constitutionalism as a means of creating structures of deliberation and decisionmaking, the better to promote and coordinate social action by enabling the right kinds of majorities to mobilize while the effects of their

52. See SCHWOERER, supra note 37 , at $281-91$.

53. I should concede, though, that early modern definitions of revolution retain the astronomical connotation of a return to an original position, not the creation of brave new worlds. 
evil "factious" twins are somehow neutralized. This is a constitutionalism whose center of gravity has shifted in notable ways. ${ }^{54}$

Among the forms of deliberation this positive variety of constitutionalism requires, that of drafting and ratifying the constitution itself must rank high. Here (at last) we return to the concern with the peculiar importance of a doctrine of ratification that Ackerman's account of the Federalists neglects. As Samuel Beer notes, English republicanism did lay a basis for the American concept of ratification. In Harrington's Oceana, a "council of prytans" would assist the "council of legislators" in drafting an agreement which would then be submitted to the small parish assemblies for approval. ${ }^{55}$ But in other sources that might be brought to bear on this question, the question of obtaining popular consent to a constitutional compact seems to smack more of securing loyalty in a time of revolutionary turmoil than of fostering moderate, truth-seeking debate of the kind described by Hamilton in Federalist No. $I$ or Madison in Federalist No. 37. When opposition to a constituted government or participation in an act of "dissolution" verges on sedition and treasonwhich was necessarily the case in the $1640 \mathrm{~s}, 1650 \mathrm{~s}$, and 1680s-the first imperative is not to compare schemes of government on their merits but to secure obedience in the hope that loyalty and affection will eventually follow. Thus the Levellers would have obtained consent to their Agreement of the People not by holding ratification conventions but by circulating the document, like a petition, to the people for their signature. Hobbes's discussion of the formation of a "Common-wealth by Institution" in Leviathan is concerned not with the mechanism by which the people covenant with one another to embody a sovereign, but rather with making the would-be covenanters understand the depth of their obedience to the sovereign. ${ }^{56}$ As Quentin Skinner has suggested, the Engagement controversy framed a significant part of the context within which Leviathan took its final form; and that controversy revolved around whether or not one should subscribe to a loyalty oath promising obedience to the Commonwealth currently reigning in the wake of the execution of Charles I and the abolition of the monarchy and the House of Lords. ${ }^{57}$ And even in the Second Treatise, Locke's interest lies far more in explaining when a

54. Students, colleagues, and general admirers of Samuel Beer will recognize my debt to his treatment of Anglo-American constitutionalism in SAMUEL BEER, TO MAKE A NATION (1993). By the same token, this account of the relation between English and American concems owes much to JOHN PHLLIP REID, CONSTITUTIONAL HISTORY OF THE AMERICAN REVOLUTTON (1993) (4 vols.).

55. BEER, supra note 54, at 310-12.

56. See ThOMAS HoBbes, Leviathan, ch. xviii (C.B. Macpherson ed., Penguin Books 1968) (1651).

57. See Quentin Skinner, Conquest and Consent: Thomas Hobbes and the Engagement Controversy, in THE INTERREGNUM: THE QUEST FOR SETTLEMENT 1640-1660, at $79-98$ (G.E. AYLMER ed., 1972). 
situation of "dissolution" permitting an "appeal to heaven" exists than in describing in positive terms the modalities of forming a commonwealth.

In sum, whatever precedent the events of 1688 and 1689 set for the Americans of 1787 or 1866 , the differences and outright contrasts between the English and American contexts appear far more noteworthy than their similarities. All three episodes involved, to be sure, forays into radical acts of doubtful constitutionality or legality; all three acquired both legitimacy and an ultimate legality through risky acts of political entrepreneurship. But in 1787 and 1788, that political risk-taking was made possible by doctrinal developments that the English had evaded, even though their most formidable political thinkers at least glimpsed the problems entailed.

\section{READING THE (WHOLE) FEDERALIST}

In his first Storrs lecture, Ackerman urged his audience-presumably comprised primarily of professors and students of law, though addressed equally as citizens-to read The Federalist. But it was not to be read quite in the manner of Alexander Bickel, the dominant figure in Yale constitutional theory, who in posing the countermajoritarian dilemma had taken Hamilton's discussion of judicial review in Federalist No. 78 as both his point of departure and the source of the title of his most influential work. Ackerman warned against what might be called the "law-office history" mode of citation which inclined dabbling readers to "cit[e] it for a catchphrase while dismissing the larger conception of constitutional government that gives the slogan life." 58 Yet it is hard to resist the conclusion that a key passage in Madison's Federalist No. 40 serves essentially the same function for Ackerman's interpretation as Hamilton's Federalist No. 78 did for Bickel's. For while other essays-most notably the old standby, Federalist No. 10-make an occasional appearance, the text that Ackerman repeatedly invokes is the one in which Madison drops the mask and boldly asserts that an appeal to "the people.themselves" could "blot out antecedent errors and irregularities" in the means by which the Federal Convention had assembled.

Fair enough: Madison's declaration is authentic, revealing, and well "worth pondering," in just the way that Ackerman suggests. Yet Federalist No. 40 has a greater importance in Ackerman's interpretative scheme, for he wants us

58. Ackerman, supra note 1, at 1016 (1984), alluding to ALEXANDER BICKEL, THE LEAST DANGEROUS BRANCH (1962). Like other historians, I have benefited from the treatment of Yalebased constitutional theory in LAURA KALMAN, THE STRANGE CAREER OF LEGAL LIBERALISM (1996). For my own partial thoughts on the manner in which Bickel posed the countermajoritarian dilemma, see Jack N. Rakove, The Origins of Judicial Review: A Plea for New Contexts, 49 STAN. L. REV. 1031, 1035-37 (1997). 
to approach the Framers as if they might serve as the paradigmatic example of a continuing constitutional possibility-that despite the countless diversions of private citizenship, we may, once again, speak in the higher law accents of We the People of the United States. Given this effort to rediscover the democratic foundations of our Constitution, the founding Convention's departure from preexisting forms of higher lawmaking cannot be treated as if it were an anomaly from a bygone age. Instead, by explicitly allowing future Conventions to regain the center of the constitutional stage, the Framers themselves caution future generations of Americans against assuming that the last act of the American Revolution was played out by the first Constitutional Convention. ${ }^{59}$

In effect, the Framers seem to want or at least invite us to emulate their example.

As it happens, the Framer on whom Ackerman relies most did indeed address some cautions to Americans (past, present, and future) on the merits of appealing to "the people themselves" in the pursuit of constitutional change. These cautions appear most strongly in Federalist Nos. 49 and 50, two essays whose import and theoretical power are, I think, strangely neglected, even amid the numerous scholarly commentaries devoted to Publius. These two essays appear as a sort of diversion in the set of five essays (Federalist Nos. 47-51) that Madison devoted to appraising and recasting the doctrine of separation of powers. At first glance, the other three essays seem to pack greater interpretative wallop: No. 47 , by explicating "the celebrated Montesquieu" and comparing his theory to American practice ${ }^{60}$ No. 48 , by explaining why the legislature is the most dangerous branch, "drawing all power into its impetuous vortex"; $;{ }^{61}$ and No. 51 , by arguing that "Ambition must be made to counteract ambition" 62 while revealingly concluding by restating the general theory of Federalist No. 10. By comparison, essays No. 49 and No. 50 seem to meander into a byway, examining a proposal that was manifestly not before the sovereign American public in 1788: Jefferson's idea, as expressed in an appendix to his Notes on the State of Virginia, for correcting threatened breaches in the constitutional balance by calling special conventions at the request of any two of the three departments of government. Notwithstanding the use of the magic word, convention, in this proposal, Ackerman devotes scant attention to these essays, and his treatment of their import is less than full. ${ }^{63}$

59. Ackerman, supra note 1, at 1060. By "Conventions," of course, Ackerman does not mean only those meetings called in accordance with the requirements of Article $\mathrm{V}$.

60. THE FEDERALIST No. 47, at 337 (James Madison) (Benjamin Fletcher Wright ed., 1961).

61. THE FEDERALIST No. 48, at 343 (James Madison) (Benjamin Fletcher Wright ed., 1961).

62. THE FEDERALIST No. 51, at 356 (James Madison) (Benjamin Fletcher Wright ed., 1961).

63. See 1 ACKERMAN, supra note 2, at 175-78. 
A few weeks prior to writing these essays, Madison had dropped the mask in another way in an extremely revealing letter to his "dear friend" Edmund Randolph. It was Randolph, of course, who had presented the Virginia Plan to the Convention but who had finally refused to sign the finished Constitution, and who was now trimming his way back toward the Federalist stance he would take when the Virginia ratification convention finally assembled in June 1788. For now, however, Randolph thought that a second constitutional convention should be held, to correct the errors of the first and to incorporate in the revised document the sentiments of the people. Madison dismissed this idea as utter madness. Part of his opposition was grounded in the strategic fear that outright opponents of the Constitution would gain election and do their best to block any agreement. But then he added a second, more telling reason for his skepticism:

But were the first difficulties overcome, and the Constitution reedited with amendments, the event would still be infinitely precarious. Whatever respect may be due to the rights of private judgment, and no man feels more of it than I do, there can be no doubt that there are subjects to which the capacities of the bulk of mankind are unequal, and on which they must and will be governed by those with whom they happen to have acquaintance and confidence. The proposed Constitution is of this description. The great body of those who are both for \& against it, must follow the judgment of others not their own. Had the Constitution been framed \& recommended by an obscure individual, instead of a body possessing public respect and confidence, there can not be a doubt, that altho' it would have stood in identical words, it would have commanded little attention from most of those who now admire its wisdom.... I infer from these considerations that if a Government be ever adopted in America, it must result from a fortunate coincidence of leading opinions, and a general confidence of the people in those who may recommend it. ${ }^{64}$

One element of this tellingly frank letter-the mobilization of established leaders to guide public opinion-might be roughly compatible with Ackerman's model of the process of transformation, but it takes some stretching of the political imagination to understand how Madison's sentiments can be reconciled with the normative claims of We the People.

Federalist Nos. 49 and 50 represent the public expression of these privately voiced sentiments. For the radical conclusion to which Madison's analysis of Jefferson's proposal points is that no extraordinary appeal to public opinion to resolve constitutional disputes should ever be attempted.

64. Letter from James Madison to Edmund Randolph (Jan. 10, 1788), in 10 THE PAPERS OF MADISON, at 355-56 (Robert A. Rutland et al. eds., 1977). 
While conceding that a "recurrence to the people" was consistent with the theory of popular sovereignty, Madison leveled three criticisms against Jefferson's proposal..$^{65}$ First, "frequent appeals" of this kind "would... deprive the government of that veneration which time bestows on every thing," sapping "the reverence for the laws" and the useful "prejudices of the community" that government requires. ${ }^{66}$ Second, future occasions were likely to be less favorable to the process of constitutional revision that Americans had recently (and presumably still) enjoyed. Constitutional "experiments are of too ticklish a nature to be unnecessarily multiplied." ${ }^{67}$ Third, and most importantly, Madison suggested that public discussion and decision of a constitutional dispute

could never be expected to turn on the true merits of the question. It would inevitably be connected with the spirit of preexisting parties, or of parties springing out of the question itself. It would be connected with persons of distinguished character and extensive influence in the community. It would be pronounced by the very men who had been agents in, or opponents of, the measures to which the decision would relate. The passions, therefore, not the reason, of the public would sit in judgment. But it is the reason, alone, of the public, that ought to control and regulate the government. The passions ought to be controlled and regulated by the government. ${ }^{68}$

Read literally, Madison's analysis seems to suggest that no subsequent constitutional dispute could ever be safely referred to the people. Just as there was no Rawlsian veil of ignorance behind which the people could ever step, so there was no disinterested, rational basis on which the people could ever adjudicate a deep constitutional controversy. And perhaps more troubling still, Madison's analysis of the likely sources of constitutional disequilibrium illustrates his belief that the people themselves would be the most likely sources of the disputes that would require regulation-because, after all, it was the popularly elected lower House in which the "impetuous vortex" of legislative power would swirl most turbulently. ${ }^{69}$

This admittedly bleak account of Madison's doubts about the capacity of an engaged citizenry to comprehend and act upon difficult questions would seem to have at least these implications for an assessment of Ackerman's theory. While it obviously does not affect the empirical claim

65. THE FEDERALIST No. 49, at 348 (James Madison) (Benjamin Fletcher Wright ed., 1961).

66. Id. at 349 .

67. Id.

68. Id. at 351 .

69. I draw here on my analysis of these essays in RAKOVE, supra note 20 , at $140-41,280-82$, and the further discussion of the implications of Madison's concern with popular misrule for his early notions of constitutional interpretation in $i d$. at 345-55. 
that subsequent constitutional change, equivalent to amendment, has occurred outside Article $\mathrm{V}$, it muddies the normative approval that Ackerman seeks to derive from the Founders' anticipation that future situations might require equally bold ventures in political entrepreneurship. It is not Madison the Founder of 1787 and 1788 whom Ackerman should call from the vasty deep of constitutional history-though perhaps Madison the Party Warrior of 1798 might fit the bill better. Fixated as that earlier Madison was on the belief that the interested, opinionated, and impassioned impulses of the people would be the preponderant sources of constitutional disequilibria, the last possibility that he wanted to contemplate was that the people would ever be called upon to speak so vigorously again. In the womb of time, no one could predict what future decades, generations, or centuries would produce; but to the extent that Madison gazed into the future, he seemed to hope that all future constitutional change would occur within the exclusio alterius bounds of Article V.

None of this is to claim that Ackerman is normatively wrong to challenge the adequacy of Article $\mathrm{V}$ to account for later fundamental changes. It simply says that the historical foundations on which that normative theory rests cannot support the weight they are asked to bear. Federalist No. 40 is certainly a revealing text, and it captures an important element in Federalist principles and practice. But Federalist Nos. 49 and 50 are no less revealing. A historical account of either Madison's thinking in particular or Federalist theory in general should seek a way either to reconcile these tensions or examine their incompatibility. A theory of constitutional change that picks and chooses the texts that best support its position may still be good theory, but its strengths may lie elsewhere than in its justice to the historical record.

\section{CONCLUSION}

This essay expresses three general criticisms of the treatment of the Founding in We the People. It suggests, first, that Ackerman's rhetorical emphasis on the "illegality" and "end-run" dimensions of the Federalist campaign to supplant the Articles of Confederation, though correct in itself, ignores the arguably more important half of the story. This neglected half explains how substantive changes in American constitutional doctrine in the years leading up to 1787 encouraged and even required the Federalists to pursue a strategy of framing and ratifying the Constitution that would manifestly establish its super-legality as well as its legitimacy. Second, the contrast between the incomplete English antecedents of the Stuart era and the robust developments of the American Revolution deepens our understanding of the same achievement by demonstrating how Americans converted the tentative speculations of their political ancestors into a set of 
procedures and a doctrine that proved essential to the foundation of a new constitutional regime. Third, Ackerman's truncated account of American doctrine in general and Madisonian thinking in particular exposes We the People to the charge that it is, in the end, yet another exercise in the partial appropriation of historical materials for theoretical ends. In such an exercise, it is inevitable that the historian's tolerance for-indeed, addiction to-ambiguity cannot be allowed to trump the rhetorical demands of advocacy. And if nothing else, We the People is as advocatorial a work of normative constitutional theory as one can ever imagine encountering. 